\title{
Technical note: Adjustment of traditional cow evaluations to improve accuracy of genomic predictions
}

\author{
G. R. Wiggans, ${ }^{1}$ T. A. Cooper, P. M. VanRaden, and J. B. Cole \\ Animal Improvement Programs Laboratory, Agricultural Research Service, USDA, Beltsville, MD 20705-2350
}

\begin{abstract}
Genomic evaluations are calculated using deregressed predicted transmitting abilities (PTA) from traditional evaluations to estimate effects of single nucleotide polymorphisms. The direct genomic value (sum of an animal's marker effects) should be consistent with traditional PTA, which is the case for bulls. However, traditional PTA of yield traits (milk, fat, and protein) for genotyped cows are higher than their direct genomic values. To ensure that characteristics of cow PTA for yield traits were more similar to those for bull PTA, mean and variance of cow Mendelian sampling (PTA minus parent average) were adjusted to be similar to those of bulls. The same adjustments were used for all genotyped cows in a breed. To determine gains in reliabilities, predictions were made for bulls with August 2010 evaluations that did not have traditional evaluations in August 2006. By adjusting cow PTA and parent averages of genotyped animals, Holstein and Jersey regressions of August 2010 deregressed PTA on genomic evaluations based on August 2006 data became closer to 1 for the adjusted predictor population compared with the unadjusted predictor population. Evaluation bias was decreased for Holsteins when the predictor population was adjusted. Mean gain in reliability over parent average increased 3.5 percentage points across yield traits for Holsteins and 0.9 percentage points for Jerseys when the predictor population was adjusted. The accuracy of genomic evaluations for Holsteins and Jerseys was increased through better use of information from cows.
\end{abstract}

Key words: genetic evaluation, genomic prediction, evaluation accuracy, bias

\section{Technical Note}

Genomic evaluations based on the BovineSNP50 Genotyping BeadChip (Illumina Inc., 2011) have revolutionized selection of dairy cattle since their introduction

Received April 25, 2011.

Accepted July 25, 2011.

${ }^{1}$ Corresponding author: George.Wiggans@ars.usda.gov in April 2008 (VanRaden et al., 2008). The evaluations are based on estimates of SNP effects derived from predictor animals, which are genotyped animals with traditional evaluations. The accuracy of all genomic evaluations increases with the size of the predictor population (VanRaden and Sullivan, 2009). For cows to contribute to accuracy, their traditional evaluations must be comparable with those of bulls. However, the evaluations of elite cows have been inflated compared with those of bulls.

Cow evaluations have been included in US genomic evaluations since their inception. Early studies (P. M. VanRaden, unpublished data) did not show much gain from doing so, but the industry was interested in including cow evaluations and hoped that a way could be found to increase their value. One problem with cow evaluations was that differences between PTA and direct genomic value (sum of an animal's marker effects) calculated with bull-only SNP effects and excluding polygenic effects were centered on 0 for bulls, but the majority of cows had a higher PTA than direct genomic value, which indicated that the traditional PTA was too high. Another problem was that some SNP effects in the pseudoautosomal region of the $\mathrm{X}$ chromosome were unusually large and appeared to be capturing a sex difference. Calculations for SNP effects should not be influenced by the gender composition of the contributing population.

One approach to decreasing inflation of cow evaluations is to decrease heritability. However, this solution was not endorsed by the industry. Preferential treatment of cow families also may cause inflated cow evaluations. Preferential treatment is defined as any management practice that increases production of a favored group of animals compared with their contemporaries and has been shown to increase bias of cow evaluations linearly (Kuhn et al., 1994). Because herd size has increased over time, preferential treatment has been assumed to be unlikely, but the high prices paid for cows with superior evaluations make superior evaluations quite valuable. Another source of bias may result from the use of external production stimulants such as bovine somatotropin (Tsuruta et al., 2000). The problem of bias extends beyond the cow herself. Bulls that have 
TECHNICAL NOTE

Table 1. Coefficients for adjustment of Holstein and Jersey yield traits

\begin{tabular}{lcccccccc}
\hline & \multicolumn{3}{c}{ Variance adjustment } & & \multicolumn{3}{c}{ Mean adjustment, $\mathrm{kg}$} \\
\cline { 2 - 4 } \cline { 7 - 9 } Breed & Milk & Fat & Protein & & Milk & Fat & Protein \\
\hline Holstein $\left(\mathrm{n}=3,559^{1}\right)$ & 0.84 & 0.72 & 0.77 & & 355.6 & 12.5 & 10.4 \\
Jersey $\left(\mathrm{n}=388^{1}\right)$ & 0.72 & 0.67 & 0.67 & & 291.7 & 14.3 & 11.0 \\
\hline
\end{tabular}

${ }^{1}$ Cows with August 2009 traditional evaluations.

daughters with biased evaluations also have inflated PTA (Kuhn and Freeman, 1995). Bias due to selection based on pedigree is present for both males and females in the genotyped population and, therefore, is not considered a female-specific cause of bias. To correct bias in traditional evaluations, methods to adjust abnormal test-day yields have been implemented (Wiggans et al., 2003).

Adjustment of cow evaluations may improve their contribution to accuracy of genomic evaluations. Canavesi and Finocchiaro (2010) investigated ways to decrease bias in evaluations of production and conformation traits of Italian bull dams. Females have not been included in the predictor populations in Canada (Schenkel et al., 2009), Germany (Reinhardt et al., 2009), and New Zealand (Spelman et al., 2010) because of concerns about bias. Spelman et al. (2010) noted a small increase in genetic gain per dollar spent on genotyping for females in New Zealand. The approach taken in the United States was to make cow evaluations more like bull evaluations so that they no longer would distort estimation of SNP effects. An adjustment was implemented in April 2010 for genotyped Holstein and Jersey cows that decreased the variance and mean of their evaluations and similarly adjusted dam contribution to parent average (PA) (Cooper et al., 2010). The objective of this report is to describe the development of the April 2010 adjustment of cow evaluations for use in genomic evaluations.

To adjust for bias in cow evaluations, values for deregressed Mendelian sampling (DMS) were calculated as $(\mathrm{PTA}-\mathrm{PA}) / \mathrm{R}$, where $\mathrm{R}=\mathrm{DE}_{\text {progeny }} /\left(\mathrm{DE}_{\text {prog- }}\right.$ eny $\left.+\mathrm{DE}_{\mathrm{PA}}+1\right)$ and $\mathrm{DE}=$ daughter equivalents (Van-
Raden and Wiggans, 1991). The DMS were made to be similar to those of bulls through variance and mean adjustments. Variance adjustment (VA) was calculated as the standard deviation of bull DMS divided by the standard deviation of cow DMS. Mean adjustment (MA) was the difference between bull and cow DMS after variance adjustment. The VA and MA were used to calculate adjusted deregressed PTA (DPTA $\left.\mathbf{D a d j}_{\text {aj }}\right)$ : DPTA $_{\text {adj }}=\mathrm{VA}(\mathrm{DMS}-\mathrm{MA})+\mathrm{PA}$. The deregression then was reversed to obtain adjusted PTA $\left(\mathbf{P T A}_{\text {adj }}\right)$ : $\mathrm{PTA}_{\text {adj }}=(1-\mathrm{R}) \mathrm{PA}+\mathrm{R}\left(\mathrm{DPTA}_{\mathrm{adj}}\right)$. Adjustments were made to yield traits for all genotyped females and the maternal portion of $\mathrm{PA}\left(\mathrm{PA}_{\text {adj }}\right)$ for all genotyped males and females. The DPTA for fat and protein percentages were not directly adjusted, but their PTA were recalculated from PTA $_{\text {adj }}$ for milk, fat, and protein yields.

The VA and MA were calculated based on cows and bulls with August 2009 traditional evaluations, which were grouped by similar evaluation reliability. Then, VA and MA each were averaged across groups so that all genotyped cows and dams of genotyped animals received the same adjustment. Development of April 2010 adjustments did not include imputed dams as defined by VanRaden et al. (2011); consequently, only adjustments for Holsteins and Jerseys are shown in Table 1 because of the small number of genotyped Brown Swiss cows.

To assess the effect of adjustment of cow evaluations on genomic prediction, 3 predictor populations were examined: (1) cows excluded (bulls-only predictor population), (2) cows included using unadjusted traditional PTA (unadjusted predictor population), and (3) cows included using $\mathrm{PTA}_{\text {adj }}$ for all genotyped

Table 2. Numbers of genotyped animals, predictor animals, and predicted bulls in August 2010 by breed

\begin{tabular}{lcccc}
\hline & & \multicolumn{2}{c}{ Predictor population $^{2}$} & \\
\cline { 2 - 3 } Breed & $\begin{array}{c}\text { All genotyped } \\
\text { animals }\end{array}$ & $\begin{array}{c}\text { Bulls } \\
\text { only }\end{array}$ & $\begin{array}{c}\text { Bulls } \\
\text { and cows }\end{array}$ & $\begin{array}{c}\text { Predicted } \\
\text { bulls }^{3}\end{array}$ \\
\hline Holstein & 49,475 & 5,824 & 8,274 & 2,975 \\
Jersey & 4,671 & 1,623 & 2,017 & 450 \\
\hline${ }^{1}$ Animals with and without traditional evaluations. & & \\
${ }^{2}$ Animals with a traditional evaluation in August 2006. & & \\
${ }^{3}$ Bulls with a traditional evaluation in August 2010. & &
\end{tabular}


Table 3. Regression of deregressed PTA from August 2010 on genomic evaluations from 2006 data for 3 predictor populations by breed

\begin{tabular}{llcccc}
\hline & & \multicolumn{3}{c}{ Predictor population } \\
\cline { 3 - 5 } Breed & Trait & Expected $^{1}$ & $\begin{array}{c}\text { Bulls } \\
\text { only }\end{array}$ & $\begin{array}{c}\text { Cows with } \\
\text { unadjusted PTA } \\
\text { and bulls }\end{array}$ & $\begin{array}{c}\text { Cows with } \\
\text { adjusted PTA } \\
\text { and bulls }\end{array}$ \\
\hline Holstein & Milk, kg & 0.93 & $0.91 \pm 0.02$ & $0.86 \pm 0.02$ & $0.90 \pm 0.02$ \\
& Fat, kg & 0.88 & $0.94 \pm 0.02$ & $0.85 \pm 0.02$ & $0.95 \pm 0.02$ \\
& Protein, kg & 0.88 & $0.87 \pm 0.02$ & $0.81 \pm 0.02$ & $0.87 \pm 0.02$ \\
& Fat, \% & & $0.99 \pm 0.01$ & $1.00 \pm 0.01$ & $1.02 \pm 0.01$ \\
Jersey & Protein, \% & & $0.87 \pm 0.01$ & $0.88 \pm 0.01$ & $0.89 \pm 0.01$ \\
& Milk, kg & 0.94 & $0.95 \pm 0.05$ & $0.92 \pm 0.05$ & $0.94 \pm 0.05$ \\
& Fat, kg & 0.91 & $0.80 \pm 0.05$ & $0.79 \pm 0.05$ & $0.81 \pm 0.05$ \\
& Protein, kg & 0.91 & $0.86 \pm 0.05$ & $0.83 \pm 0.05$ & $0.86 \pm 0.05$ \\
& Fat, \% & & $0.91 \pm 0.03$ & $0.91 \pm 0.03$ & $0.93 \pm 0.04$ \\
& Protein, \% & & $0.83 \pm 0.04$ & $0.85 \pm 0.04$ & $0.88 \pm 0.04$ \\
\hline
\end{tabular}

${ }^{1}$ Expected regression coefficient (Olson et al., 2011).

cows and $\mathrm{PA}_{\text {adj }}$ for genotyped bulls and cows (adjusted predictor population). For each of the predictor populations, genotyped animals with a traditional evaluation by April 2006 were evaluated based on their ability to predict performance of young bulls in August 2010 using a cut-off study as described by VanRaden et al. (2009). Predicted bulls were required to have received an evaluation between August 2006 and August 2010 and have $\geq 10$ daughters with traditional evaluations. The numbers of genotyped animals, animals in the predictor populations, and predicted bulls are reported in Table 2.

Regressions of August 2010 DPTA on genomic evaluations from August 2006 data (Table 3) were close to 1 for Holsteins (0.81 to 1.02 across predictor populations). Regression coefficients should be close to 1 or the expected regression coefficients calculated by Olson et al. (2011) for a 1-unit difference in genomic evaluation to result in a 1-unit change in the trait. Using the unadjusted predictor population resulted in regression coefficients furthest from 1 . With the bulls-only predictor population, regressions were improved by a mean of 0.07 across milk, fat, and protein yields. With the adjusted predictor population, regressions were closer to 1 compared with the unadjusted predictor population. Regression coefficients were smaller for Jerseys (0.79 to 0.95) than for Holsteins. As with Holsteins, regressions were closer to 1 for the bulls-only predictor population than for the unadjusted predictor population; for Jerseys, the improvement averaged 0.02 for milk, fat, and protein yields.

Bias was defined as 2010 DPTA minus 2006 genomic evaluation (Table 4). A negative bias indicated that an animal's genomic prediction was higher than its 2010 DPTA. Bias should be close to 0. Bias was decreased for Holsteins but increased for Jerseys when the predictor population was adjusted.

For Holsteins, realized reliability (VanRaden et al., 2009) of bull genomic predictions (Table 5) was lowest for the unadjusted predictor population, with a mean

Table 4. Evaluation bias ${ }^{1}$ for 3 predictor populations by breed

\begin{tabular}{|c|c|c|c|c|}
\hline \multirow[b]{2}{*}{ Breed } & \multirow[b]{2}{*}{ Trait } & \multicolumn{3}{|c|}{ Predictor population } \\
\hline & & $\begin{array}{l}\text { Bulls } \\
\text { only }\end{array}$ & $\begin{array}{c}\text { Cows with } \\
\text { unadjusted PTA } \\
\text { and bulls }\end{array}$ & $\begin{array}{l}\text { Cows with } \\
\text { adjusted PTA } \\
\text { and bulls }\end{array}$ \\
\hline \multirow[t]{5}{*}{ Holstein } & Milk, kg & $-55.6 \pm 7.6$ & $-56.7 \pm 7.6$ & $-3.0 \pm 6.8$ \\
\hline & Fat, $\mathrm{kg}$ & $-3.2 \pm 0.3$ & $-2.9 \pm 0.3$ & $-1.0 \pm 0.3$ \\
\hline & Protein, kg & $-1.1 \pm 0.2$ & $-0.9 \pm 0.2$ & $0.6 \pm 0.2$ \\
\hline & Fat, $\%$ & $0.0 \pm 0.0$ & $0.0 \pm 0.0$ & $0.0 \pm 0.0$ \\
\hline & Protein, \% & $0.0 \pm 0.0$ & $0.0 \pm 0.0$ & $0.0 \pm 0.0$ \\
\hline \multirow{5}{*}{ Jersey } & Milk, kg & $0.4 \pm 13.8$ & $0.4 \pm 13.9$ & $63.2 \pm 12.3$ \\
\hline & Fat, kg & $1.9 \pm 0.6$ & $1.8 \pm 0.6$ & $4.5 \pm 0.5$ \\
\hline & Protein, $\mathrm{kg}$ & $0.2 \pm 0.5$ & $0.2 \pm 0.5$ & $2.4 \pm 0.4$ \\
\hline & Fat, $\%$ & $0.0 \pm 0.0$ & $0.0 \pm 0.0$ & $0.0 \pm 0.0$ \\
\hline & Protein, $\%$ & $0.0 \pm 0.0$ & $0.0 \pm 0.0$ & $0.0 \pm 0.0$ \\
\hline
\end{tabular}

${ }^{1}$ Bias $=2010$ deregressed value -2006 genomic evaluation. 
Table 5. Realized reliability ${ }^{1}(\%)$ of bull $^{2}$ genomic predictions for 3 predictor populations by breed

\begin{tabular}{llccc}
\hline & & \multicolumn{3}{c}{ Predictor population } \\
\cline { 3 - 5 } Breed & Trait & $\begin{array}{c}\text { Bulls } \\
\text { only }\end{array}$ & $\begin{array}{c}\text { Cows with } \\
\text { unadjusted PTA } \\
\text { and bulls }\end{array}$ & $\begin{array}{c}\text { Cows with } \\
\text { adjusted PTA } \\
\text { and bulls }\end{array}$ \\
\hline Holstein & Milk, kg & 65.3 & 63.1 & 66.1 \\
& Fat, kg & 73.0 & 69.4 & 73.5 \\
& Protein, kg & 61.3 & 58.1 & 61.6 \\
& Fat, $\%$ & 85.8 & 76.2 & 86.7 \\
Jersey & Protein, $\%$ & 75.4 & 54.5 & 57.7 \\
& Milk, kg & 54.8 & 50.9 & 51.0 \\
& Fat, kg & 50.9 & 49.4 & 51.3 \\
& Protein, kg & 50.1 & 66.0 & 65.8 \\
& Fat, $\%$ & 64.7 & 62.2 & 64.0 \\
\hline & Protein, $\%$ & 58.8 & &
\end{tabular}

of 63.5 percentage points for milk, fat, and protein yields. For the bulls-only predictor population, realized reliability increased to a mean of 66.5 percentage points across those yield traits. For the adjusted predictor population, mean realized reliability increased to 67.1 percentage points. For Jerseys, realized reliabilities across milk, fat, and protein yields were lower than for Holsteins but with similar differences between predictor populations (51.6 percentage points for the unadjusted predictor population, 51.9 percentage points for the bulls-only predictor population, and 52.5 percentage points for the adjusted predictor population).

The difference between unadjusted and adjusted predictor populations in mean reliability gain over PA for milk, fat, and protein yields increased by 3.5 percentage points for Holstein bulls and 0.9 percentage points for Jersey bulls (Table 6). Reliability gains for the adjusted predictor population can be compared with gains from adding predictor animals to the population. Official reliabilities in April 2010 and February 2011 were compared for Holstein bulls that were $<2$ yr old at each evaluation. Between those 2 evaluations, 7,948 predictor animals were added to the population for estimating SNP effects. Mean genomic reliability for milk, fat, and protein yields increased by 3.8 percentage points for young bulls, which indicates that including cows with PTA $_{\text {adj }}$ in the predictor population had a value in increasing reliability gain over PA similar to the addition of the 7,948 predictor animals.

To investigate differences in estimates of SNP effects because of changes in predictor population, Manhattan plots for Holstein yield traits were created for the unadjusted and adjusted predictor populations. Most of the 43,382 SNP had small effects on protein yield that were distributed evenly across all chromosomes (Figure 1). For the unadjusted predictor population, a large SNP effect on protein yield was found in the pseudoautosomal region of the $\mathrm{X}$ chromosome $\left(\mathbf{X}_{\mathbf{P A R}}\right)$. However, that large SNP effect was no longer present for the adjusted predictor population. Manhattan plots for milk and fat yields (not shown) followed similar patterns. Although the model for genomic prediction does

Table 6. Reliability from bull ${ }^{1}$ parent average (PA) and gains over PA from including genomic predictions for 3 predictor populations by breed

\begin{tabular}{|c|c|c|c|c|c|}
\hline \multirow[b]{2}{*}{ Breed } & \multirow[b]{2}{*}{ Trait } & \multirow[b]{2}{*}{$\mathrm{PA}^{1}$} & \multicolumn{3}{|c|}{ Predictor population } \\
\hline & & & $\begin{array}{l}\text { Bulls } \\
\text { only }\end{array}$ & $\begin{array}{c}\text { Cows with } \\
\text { unadjusted PTA } \\
\text { and bulls }\end{array}$ & $\begin{array}{l}\text { Cows with } \\
\text { adjusted PTA } \\
\text { and bulls }\end{array}$ \\
\hline \multirow[t]{5}{*}{ Holstein } & Milk, kg & 37.8 & 27.5 & 25.3 & 28.3 \\
\hline & Fat, kg & 37.8 & 35.2 & 31.6 & 35.7 \\
\hline & Protein, kg & 37.8 & 23.5 & 20.3 & 23.8 \\
\hline & Fat, $\%$ & 37.8 & 48.0 & 48.4 & 48.9 \\
\hline & Protein, \% & 37.8 & 37.6 & 38.4 & 39.9 \\
\hline \multirow[t]{5}{*}{ Jersey } & Milk, kg & 39.0 & 15.8 & 15.5 & 16.2 \\
\hline & Fat, kg & 39.0 & 11.9 & 11.9 & 12.0 \\
\hline & Protein, kg & 39.0 & 11.1 & 10.4 & 12.3 \\
\hline & Fat, $\%$ & 39.0 & 25.7 & 27.0 & 26.8 \\
\hline & Protein, $\%$ & 39.0 & 19.8 & 23.2 & 25.0 \\
\hline
\end{tabular}

${ }^{1}$ Bulls with a traditional evaluation in August 2010. 
not include a specific effect for sex, sex differences may be expressed at $\mathrm{X}_{\mathrm{PAR}}$ because cows carry 2 copies of SNP there, whereas bulls carry only 1 copy. When cow and bull allele frequencies were similar, $\mathrm{X}_{\mathrm{PAR}}$ accounted for the differences in cow and bull PTA due to bias in cow PTA. When bias was removed from cow PTA in the adjusted predictor population, $\mathrm{X}_{\mathrm{PAR}} \mathrm{SNP}$ effects were decreased to more typical levels.

The adjustment implemented in April 2010 made genomic evaluations not comparable with traditional evaluations for cows. To address that problem, a more comprehensive adjustment of all cow evaluations was implemented in April 2011 so that evaluations of nongenotyped cows would be comparable with those of genotyped cows.

Another industry concern was that the large number of cows recently being genotyped with a low-density marker panel might not require the same adjustment as genotyped cows used to estimate the April 2010 adjustment. Because the accuracy of genomic evaluations continues to increase as the number of predictor animals increases, including cows with adjusted tradi-
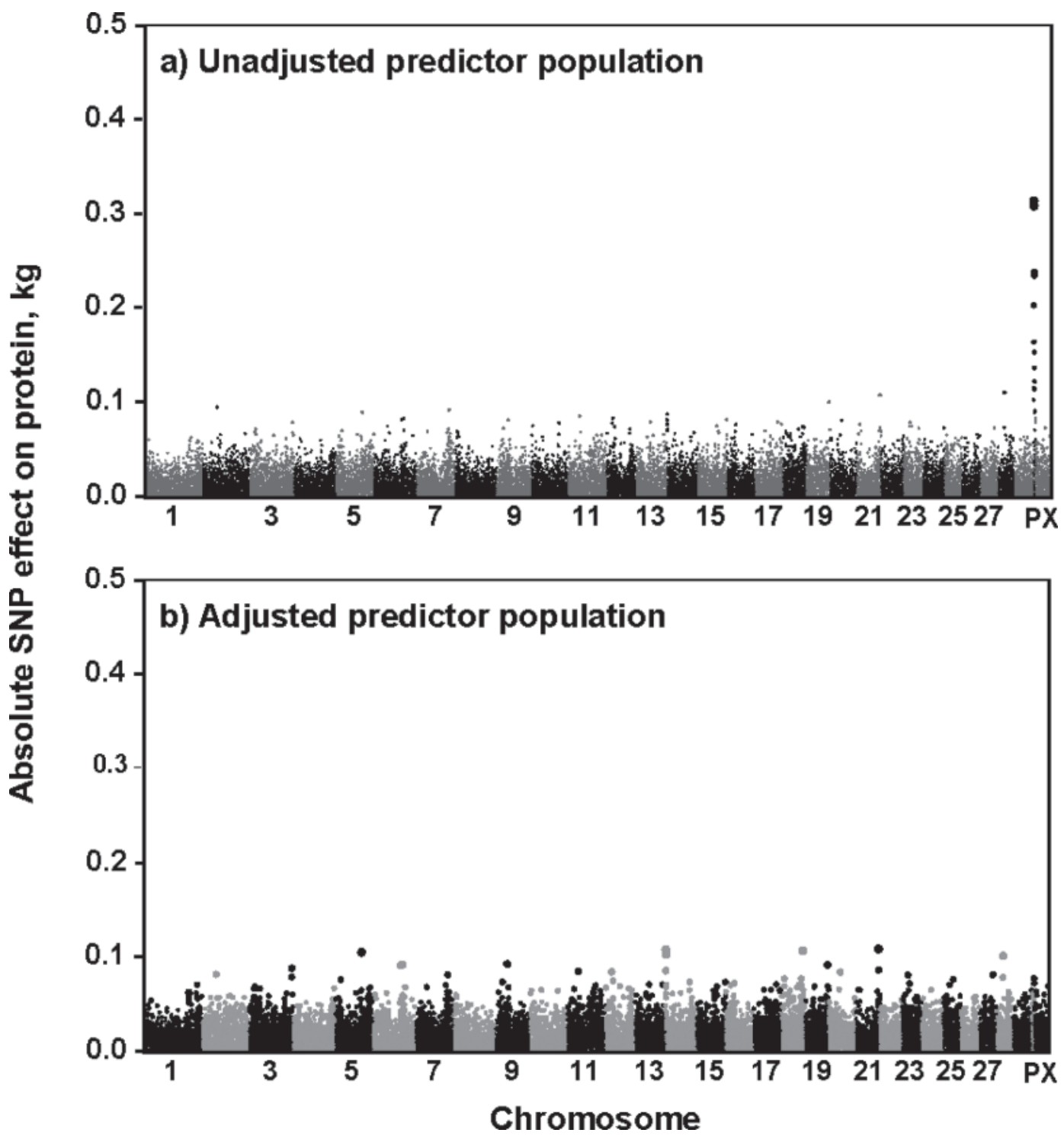

Figure 1. Distribution of absolute values for SNP effects on Holstein protein yield by chromosome $(\mathrm{P}=$ pseudoautosomal region of $\mathrm{X}$ chromosome) based on (a) an unadjusted predictor population (genotyped bulls and genotyped cows with traditional PTA in August 2006) or (b) an adjusted predictor population (genotyped bulls with PTA that includes maternally adjusted parent average and genotyped cows with adjusted PTA and maternally adjusted parent average); each SNP is designated by $\bullet$, which is proportional in size to the value of the SNP effect. 
tional evaluations should give more accurate genomic predictions than can be obtained by using only bulls for the predictor population.

\section{ACKNOWLEDGMENTS}

The authors recognize contributions from J. P. Chesnais (Semex Alliance, Ottawa, Ontario, Canada), who provided suggestions and advice on the project. The role of dairy records processing centers (AgriTech Analytics, Visalia, CA; AgSource Cooperative Services, Verona, WI; and Dairy Records Management Systems, Raleigh, NC, and Ames, IA) in supplying the data supporting genetic evaluations is acknowledged. Two anonymous reviewers are also thanked for their thoughtful comments and review of the manuscript.

\section{REFERENCES}

Canavesi, F., and R. Finocchiaro. 2010. Investigating bull dam bias in national genetic evaluations. J. Dairy Sci. 89(E-Suppl. 1):534. (Abstr.)

Cooper, T. A., M. E. Tooker, P. M. VanRaden, G. R. Wiggans, and J. B. Cole. 2010. Imputation of cow genotypes and adjustment of PTAs. AIPL Res. Rep. Genomic1 (4-10). Accessed July 8, 2011. http://aipl.arsusda.gov/reference/changes/aprilInformation.htm.

Illumina Inc. 2011. BovineSNP50 Genotyping BeadChip. Accessed June 29, 2011. http://www.illumina.com/Documents/products/ datasheets/datasheet_bovine_snp50.pdf.

Kuhn, M. T., P. J. Boettcher, and A. E. Freeman. 1994. Potential biases in predicted transmitting abilities of females from preferential treatment. J. Dairy Sci. 77:2428-2437.

Kuhn, M. T., and A. E. Freeman. 1995. Biases in predicted transmitting abilities of sires when daughters receive preferential treatment. J. Dairy Sci. 78:2067-2072.
Olson, K. M., P. M. VanRaden, M. E. Tooker, and T. A. Cooper. 2011. Differences among methods to validate genomic evaluations for dairy cattle. J. Dairy Sci. 94:2613-2620.

Reinhardt, F., Z. Liu, F. Seefried, and G. Thaller. 2009. Implementation of genomic evaluation in German Holsteins. Interbull Bull. 40:219-226.

Schenkel, F. S., M. Sargolzaei, G. Kistemaker, G. B. Jansen, P. Sullivan, B. J. Van Doormaal, P. M. VanRaden, and G. R. Wiggans. 2009. Reliability of genomic evaluation of Holstein cattle in Canada. Interbull Bull. 39:51-58.

Spelman, R. J., J. Arias, M. D. Keehan, V. Obolonkin, A. M. Winkelman, D. L. Johnson, and B. L. Harris. 2010. Application of genomic selection in the New Zealand dairy cattle industry. Commun. No. 0311 in Proc. 9th World Congr. Genet. Appl. Livest. Prod., Leipzig, Germany. Gesellschaft für Tierzuchtwissenschaften e. V., Gießen, Germany.

Tsuruta, S., J. F. Keown, L. D. Van Vleck, and I. Misztal. 2000. Bias in genetic evaluations by records of cows treated with bovine somatotropin. J. Dairy Sci. 83:2650-2656.

VanRaden, P.. G. Wiggans, C. Van Tassell, T. Sonstegard, and L. Walton. 2008. Genomic prediction. Changes to evaluation system (April 2008). Accessed June 29, 2011. http://aipl.arsusda.gov/reference/changes/eval0804.html.

VanRaden, P. M., J. R. O'Connell, G. R. Wiggans, and K. A. Weigel. 2011. Genomic evaluations with many more genotypes. Genet. Sel. Evol. 43:10.

VanRaden, P. M., and P. G. Sullivan. 2009. National and international genomic evaluations for dairy cattle. J. Dairy Sci. 92(E-Suppl. 1):175.

VanRaden, P. M., C. P. Van Tassell, G. R. Wiggans, T. S. Sonstegard, R. D. Schnabel, J. F. Taylor, and F. S. Schenkel. 2009. Invited review: Reliability of genomic predictions for North American Holstein bulls. J. Dairy Sci. 92:16-24.

VanRaden, P. M., and G. R. Wiggans. 1991. Derivation, calculation, and use of national animal model information. J. Dairy Sci. 74:2737-2746.

Wiggans, G. R., P. M. VanRaden, and J. C. Philpot. 2003. Technical note: Detection and adjustment of abnormal test-day yields. J. Dairy Sci. 86:2721-2724. 